OPEN ACCESS

Edited by:

Daniele Vergara,

University of Salento, Italy

Reviewed by:

Sara Sergio,

University of Salento, Italy

Amilcare Barca,

University of Salento, Italy

*Correspondence:

Xavier Busquets

xavier.busquets@uib.es

tThese authors have contributed equally to this work and share senior

authorship

Specialty section:

This article was submitted to Lipid and Fatty Acid Research,

a section of the journal

Frontiers in Physiology

Received: 24 September 2021 Accepted: 28 October 2021

Published: 20 January 2022

Citation:

Fernández-Díaz $J$

Beteta-Göbel R, Torres M, Cabot J, Fernández-García P, Lladó V, Escribá PV and Busquets X (2022) Tri-2-Hydroxyarachidonein Induces Cytocidal Autophagy in Pancreatic Ductal Adenocarcinoma Cancer Cell Models. Front. Physiol. 12:782525. doi: 10.3389/fphys.2021.782525

\section{Tri-2-Hydroxyarachidonein Induces Cytocidal Autophagy in Pancreatic Ductal Adenocarcinoma Cancer Cell Models}

\author{
Javier Fernández-Díaz', Roberto Beteta-Göbel', Manuel Torres ${ }^{1}$, Joan Cabot ${ }^{1}$, \\ Paula Fernández-García ${ }^{2}$, Victoria Lladó2 ${ }^{2}$ Pablo V. Escribá ${ }^{1 \dagger}$ and Xavier Busquets ${ }^{1 * \dagger}$ \\ 1 Laboratory of Molecular Cell Biomedicine, Department of Biology, University of the Balearic Islands, Palma de Mallorca, \\ Spain, ${ }^{2}$ Laminar Pharmaceuticals, Department of R\&D, Palma de Mallorca, Spain
}

Cell proliferation in pancreatic cancer is determined by a complex network of signaling pathways. Despite the extensive understanding of these protein-mediated signaling processes, there are no significant drug discoveries that could considerably improve a patient's survival. However, the recent understanding of lipid-mediated signaling gives a new perspective on the control of the physiological state of pancreatic cells. Lipid signaling plays a major role in the induction of cytocidal autophagy and can be exploited using synthetic lipids to induce cell death in pancreatic cancer cells. In this work, we studied the activity of a synthetic lipid, tri-2-hydroxyarachidonein (TGM4), which is a triacylglycerol mimetic that contains three acyl moieties with four double bonds each, on cellular and in vivo models of pancreatic cancer. We demonstrated that TGM4 inhibited proliferation of Mia-PaCa-2 (human pancreatic carcinoma) and PANC-1 (human pancreatic carcinoma of ductal cells) in in vitro models and in an in vivo xenograft model of Mia-PaCa-2 cells. In vitro studies demonstrated that TGM4 induced cell growth inhibition paralleled with an increased expression of PARP and $\mathrm{CHOP}$ proteins together with the presence of sub- $G_{0}$ cell cycle events, indicating cell death. This cytocidal effect was associated with elevated ER stress or autophagy markers such as BIP, LC3B, and DHFR. In addition, TGM4 activated peroxisome proliferator-activated receptor gamma (PPAR- $\gamma$ ), which induced elevated levels of p-AKT and downregulation of p-c-Jun. We conclude that TGM4 induced pancreatic cell death by activation of cytocidal autophagy. This work highlights the importance of lipid signaling in cancer and the use of synthetic lipid structures as novel and potential approaches to treat pancreatic cancer and other neoplasias.

Keywords: synthetic lipid, cell death, pancreas, signal transduction, oncology, autophagy, cancer

\section{INTRODUCTION}

The pancreatic ductal adenocarcinoma (PDAC) is the fourth leading cause of cancer death in the United States and the sixth in Europe (Jemal et al., 2009). PDAC is the most common pancreatic neoplasm, which comprises approximately $90 \%$ of all pancreatic malignancies (Ferlay et al., 2010). Advanced age together with smoking, diabetes, obesity, or pancreatitis are contemplated risk 
factors (Everhart and Wright, 1995; Gapstur et al., 2000; Michaud et al., 2001; Huxley et al., 2005). Despite recent advances in chemotherapy including gentamicin in combination with other agents, adjuvants, and immunotherapy, the survival for pancreatic cancer remains grim (Roth et al., 2020).

Cell proliferation in pancreatic cancer is determined by an enormous complex network of signaling pathways (Polireddy and Chen, 2016). K-Ras mutations are often contemplated as the main initiating event, latter followed by P16 mutations, P53, and SMAD4 loss (Jones et al., 2008). Despite the extensive familiarity of these protein-mediated signaling networks, there are no significant advances in treatment strategies. However, the recent understanding of lipid-mediated signaling gains importance in understanding the control of the physiological state of pancreatic cells (Swierczynski et al., 2014).

In this context, cancer cells to supply the requirement of membrane phospholipids due to their altered proliferative state are characterized by an activation of the fatty acid biosynthetic pathways (Swinnen et al., 2000; Kuhajda, 2006). For example, the activity of AMPK in PDAC cells is lower than in normal cells, leading to a rise in the activity of acetyl-CoA carboxylase, a key factor in lipogenesis (Adachi et al., 2011). The phosphorylation by AMPK, causing acetyl-CoA carboxylase inhibition, is one of the central stages of lipogenesis (Saha and Ruderman, 2003) together with the increased expression of/fatty acid synthase in human pancreatic cancer (Witkiewicz et al., 2008; Yang et al., 2011). The elevated levels of fatty acid synthase, both in tumor cells and in serum, are even associated with poor prognosis (Walter et al., 2009).

Interestingly, several saturated and unsaturated fatty acids modulate autophagy (Brenner et al., 2013; Niso-Santano et al., 2015). Autophagy is a cellular process that controls the recycling of macromolecules and cytoplasmic structures through phagosomes (Mizushima et al., 2008; Martinet et al., 2009). Autophagy has also been associated with the induction of nonapoptotic cell death (Miller et al., 2019). The accumulation of misfolded proteins in the endothelium reticulum results in the upregulation of the unfolded protein response (UPR) pathway and the expression of autophagy-related genes (Ogata et al., 2006; Kouroku et al., 2007). UPR and autophagy can either cause cytoprotective or cytocidal effects (Kondo et al., 2005; Moenner et al., 2007; Yonekawa and Thorburn, 2013).

Nowadays, it is well established that lipid signaling plays a major role in the induction of autophagy (Wang and Nie, 2015; Soto-Avellaneda and Morrison, 2020). The cytocidal effects of autophagy can be exploited using synthetic fatty acids to induce cell death in cancer cells and represent a promising field in cancer therapy investigation (Marcilla-Etxenike et al., 2012). In fact, autophagy is upregulated in PDAC and is regarded as a potential therapeutic target in PDAC and other cancers (Piffoux et al., 2021). Previously, we demonstrated that sustained activation of autophagy with synthetic fatty acids triggers cancer cell death (Marcilla-Etxenike et al., 2012; Teres et al., 2012; BetetaGöbel et al., 2021). In this work, we studied the activity of a synthetic triacylglycerol, TGM4, on cellular and in vivo models of pancreatic cancer. We demonstrated that TGM4 induces pancreatic cell death by the activation of autophagy. This work highlights the importance of lipid signaling in cancer and the use of synthetic lipid structures as novel and potential approaches to treat pancreatic cancer and other neoplasias.

\section{MATERIALS AND METHODS}

\section{Tri-2-Hydroxyarachidonein}

The compound, tri-2-hydroxy-eicosatetra (5E,8E,11E,14E) enoine (also tri-2-hydroxyarachidonein or TGM4; Figure 1), was kindly provided by Laminar Pharmaceuticals (Palma, Spain).

\section{Cell Culture}

Human pancreatic carcinoma (Mia-PaCa-2) and human pancreatic carcinoma of ductal cells (PANC-1) were obtained from American Type Culture Collection (ATCC). Both cell lines were maintained and grown in $75-\mathrm{cm}^{2}$ flasks with Dulbecco's modified Eagle's medium (DMEM) with phenol red including $10 \%$ of fetal bovine serum (FBS), $100 \mathrm{U} / \mathrm{ml}$ of penicillin, and $100 \mu \mathrm{g} / \mathrm{ml}$ of streptomycin supplemented with D-glucose (4.5 g/L), L-glutamine ( $4 \mathrm{mM})$, and sodium pyruvate (1 $\mathrm{mM})$. They were incubated in HEPA-filtered cell incubator (Memmert GmbH Co., United Kingdom) at $37^{\circ} \mathrm{C}$ with $95 \%$ humidified air and $5 \% \mathrm{CO}$. Cell culture experiments were carried on a laminar vertical flow cabinet (Telstar S.A., Terrasa, Spain).

\section{Cell Proliferation or Cytotoxicity Studies}

For cytotoxicity experiments, Mia-PaCa-2 and PANC-1 cell lines were seeded at a density of $3 \times 10^{3}$ cells/well into 96-well plates and incubated at $37^{\circ} \mathrm{C}$ for $24 \mathrm{~h}$ in a $\mathrm{CO}_{2}$ incubator. After $24 \mathrm{~h}$, the medium was changed and replaced with a new medium containing TGM4. To dissolve the TGM4, a stock solution of $100 \mathrm{mM}$ of TGM4 was prepared in DMSO. Then, the stock solution was dissolved in DMEM medium to obtain the desired concentration, never surpassing the $0.5 \%$ of final DMSO in the medium.

The cytotoxic effects were measured using the cell proliferation XTT kit (Roche Diagnostics, S.L. Applied Science, Barcelona, Spain). After incubation of cells with TGM4, the medium was replaced with DMED without phenol red mixed with the XTT reagents, following the instructions of the manufacturer. Then, the cells were incubated at $37^{\circ} \mathrm{C}$ until the color compound was formed. The absorbance was measured at a wavelength of $495 \mathrm{~nm}$ in a plate reader (FLUOStar OMEGA, BMG LABTECH, Germany). For statistical confidence, four independent experiments were performed. The $\mathrm{IC}_{50}$ (inhibitory concentration 50) was calculated with GraphPad Prism version 5.

\section{Cell Cycle Studies}

Human pancreatic carcinoma of ductal cells were seeded at a density of 250,000 cells into 6-cm-diameter plates and incubated at $37^{\circ} \mathrm{C}$ for $24 \mathrm{~h}$ in $\mathrm{CO}_{2}$ incubator. After $24 \mathrm{~h}$, the medium was changed and replaced with new medium containing TGM4 (20, 30 , or $40 \mu \mathrm{M}$ ). The cells were incubated for $6,12,24$, or $48 \mathrm{~h}$.

After incubation, the cells were recovered by centrifugation at $1,000 \times g$ for $5 \mathrm{~min}$ in 5 - $\mathrm{ml}$ cytometry tubes and suspended in complete media. Then, cells were detached with EDTA-trypsin 


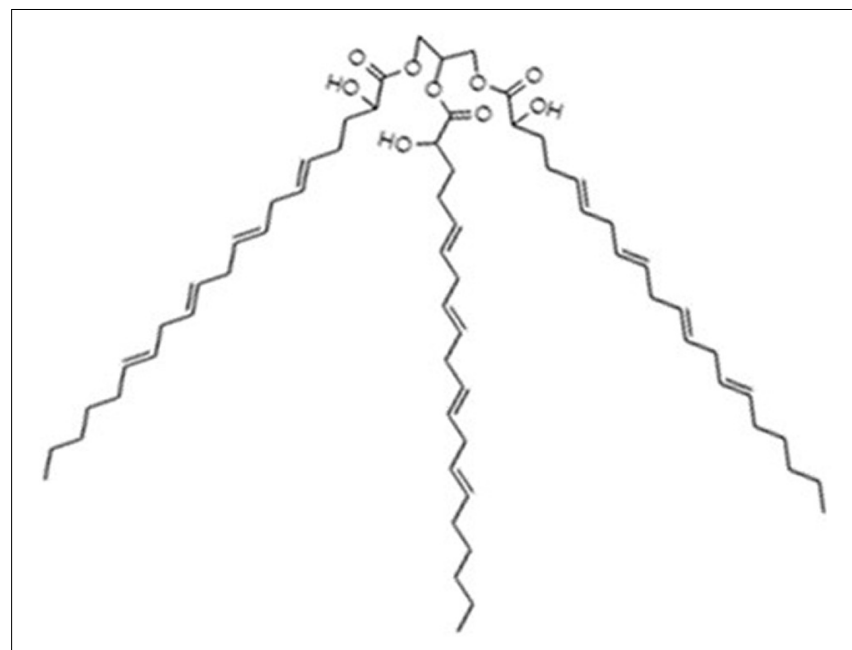

FIGURE 1 | Molecular structure of TGM4. This compound is a triacylglycerol mimetic containing three 2-hydroxyarachidonyl moieties.

and centrifuged at $1,000 \times g$ for $5 \mathrm{~min}$. The supernatant was discarded and all the cells were stored in the tube.

To fix the cells, cold $70 \%$ ethanol was added to the tube while vortexing. The tube was let overnight at $4^{\circ} \mathrm{C}$. Then, the ethanol was discarded after centrifugation at $2,500 \times g$ and $4^{\circ} \mathrm{C}$ for $5 \mathrm{~min}$. To carry out the cytometry analysis, the cells were washed with $1 \mathrm{ml}$ of sodium citrate $38 \mathrm{mM} \mathrm{pH}$ 7.4. Then, the sodium citrate was discarded after centrifuging at $2,500 \times g$ and $4^{\circ} \mathrm{C}$ for $5 \mathrm{~min}$. Finally, the cells were resuspended in $500 \mu \mathrm{l}$ of a solution containing sodium citrate

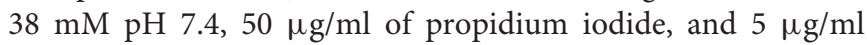
of RNase A (Sigma-Aldrich Co., St Louis, MO, United States) and incubated at $37^{\circ} \mathrm{C}$ for $20 \mathrm{~min}$. After the addition of propidium iodide, the tubes were maintained permanently in the darkness until the cytometry lecture. The flow cytometry was performed in a flow cytometer Beckman Coulter Epics XL (Beckman Coulter S.A, Madrid, Spain). The cell populations corresponding to the different phases of the cell cycle (sub-G0, G0/G1, S and G2/M) were defined through their DNA quantity (Figure 9). The results were analyzed with the software FlowJo (FlowJo, United States).

\section{Immunoblot or Western Blot Studies}

For the immunoblot studies, 325,000 PANC-1 cells were seeded into $6-\mathrm{cm}$-diameter plates and incubated at $37^{\circ} \mathrm{C}$ for $24 \mathrm{~h}$. Then, the medium was changed and replaced with new medium containing TGM4 at different concentrations.

At the desired time of treatment, the medium was discarded and the plates were washed two times with cold PBS $1 \times$ and frozen at $-80^{\circ} \mathrm{C}$. Then, $300 \mu \mathrm{l}$ of lysis buffer $(20 \mathrm{mM}$ HEPES, $2 \mathrm{mM}$ EDTA, $0.5 \mathrm{mM}$ EGTA, $1.5 \mathrm{mM} \mathrm{MgCl} 2,1 \mathrm{mM}$ cantharidine, $1 \mathrm{mM}$ orthovanadate) was added to the plate, and after $5 \mathrm{~min}$, cells were scrapped and sonicated on ice.

The protein concentration determination of each sample was performed with the protein quantification DCTM kit (Bio-Rad,
Barcelona, Spain), a colorimetric assay based on the Lowry method (Lowry et al., 1951).

The western blot was based on the work by Towbin et al. (1979). Samples were mixed with loading buffer (12 mM Tris$\mathrm{HCl} \mathrm{pH} 6.8, \beta$-mercaptoethanol, 1\%, SDS 0.2\%, bromophenol blue $0.01 \%$, and glycerol $50 \%$ ) in a $1: 10$ proportion and boiled at $95^{\circ} \mathrm{C}$ for $5 \mathrm{~min}$. Then, $30 \mu \mathrm{g}$ of whole-cell lysate of each sample was loaded on a $10 \%$ SDS polyacrylamide gel. As a protein ladder standard, 2.5-5 $\mu$ l of Precision Plus Protein all blue standard (Bio-Rad) was loaded.

The stacking gel was composed of $4 \%$ acrylamidebisacrylamide, $166 \mathrm{mM}$ Tris- $\mathrm{HCl}$ pH 6.8, 0.1\% SDS, 1\% ammonium persulfate, and $0.1 \%$ N,N, $\mathrm{N}^{\prime}, \mathrm{N}^{\prime}$ tetramethylethylenediamine. The separation gel was composed of $9.5 \%$ acrylamide-bisacrylamide, $1 \mathrm{M}$ Tris-base $\mathrm{pH}$ $8.8, \quad 0.1 \%$ SDS, $0.4 \%$ ammonium persulfate, and $0.04 \%$ $\mathrm{N}, \mathrm{N}, \mathrm{N}^{\prime}, \mathrm{N}^{\prime}$-tetramethylethylenediamine.

After loading all the samples in the SDS-polyacrylamide gels, the electrophoresis was set at $90 \mathrm{~V}$ for the stacking phase and changed to $120-140 \mathrm{~V}$ for the running phase. The electrophoresis buffer was composed of $19.2 \mathrm{mM}$ Tris-base, $0.19 \mathrm{M}$ glycine $\mathrm{pH}$ 8.6, and $0.1 \%$ SDS. When the electrophoresis was finished, the proteins into the gel were transferred to a nitrocellulose membrane (GE Healthcare, Kent, United Kingdom). The transfer process was performed in cold conditions and applying a constant amperage of 350-400 mA for $2 \mathrm{~h}$ with buffer consisting of $19.4 \mathrm{mM}$ Tris-base, $0.19 \mathrm{M}$ glycine, and $20 \%$ ethanol.

After finishing the transfer, the membrane was blocked in $5 \%$ skim milk in TBS $(50 \mathrm{mM}$ Tris- $\mathrm{HCl}, \mathrm{pH} 7.6 ; 150 \mathrm{mM}$ $\mathrm{NaCl}$ ) for $30 \mathrm{~min}$ and then incubated in primary antibodies at 1:1,000 dilution with the exception of $\alpha$-tubulin at $1: 10,000$ dilution. Primary antibody solution was prepared which contains 5\% BSA and 0.1\% Tween 20 (Sigma-Aldrich Co., St. Louis, MO, United States). The set of primary and secondary antibodies used were the following: antihuman rabbit polyclonal PARP (Santa Cruz Biotechnology, Inc., United States, \#sc7150); antihuman mouse monoclonal CHOP (Cell Signaling Technology, Inc., United States, \#2895); antihuman rabbit polyclonal BIP (Cell Signaling Technology, Inc., United States, \#3177); antihuman rabbit polyclonal LC3B (Cell Signaling Technology, Inc., United States, \#2775); antihuman mouse monoclonal DHFR (BD Transduction Laboratories, United States, \#610697); antihuman mouse monoclonal Akt 1/2/3 (Santa Cruz Biotechnology, Inc., United States, \#sc81434); antihuman rabbit polyclonal p-Akt (S473) (Cell Signaling Technology, Inc., United States, \#4060); antihuman mouse monoclonal Jun (BD-Biosciences, United States, \#J31920); antihuman rabbit polyclonal p-c-Jun (S63) (Cell Signaling Technology, Inc., United States, \#2361); and antihuman mouse monoclonal $\alpha$-tubulin (Sigma-Aldrich, United States, \#T9026).

Membranes were incubated overnight at $4^{\circ} \mathrm{C}$ and washed two times for $5 \mathrm{~min}$ with TBS and Tween $200.1 \%$. The membrane was incubated for $1 \mathrm{~h}$ in the dark with the secondary antibody (dilution 1:5,000) conjugated with a fluorochrome [IRDye 800CW Donkey Anti-Mouse IgG $(\mathrm{H}+\mathrm{L})$ or IRDye 800CW Donkey anti Rabbit IgG $(\mathrm{H}+\mathrm{L})$, LI-COR Biosciences, 
United States]. The secondary antibody was prepared in $2.5 \%$ skim milk in TBS with $0.1 \%$ Tween 20 . Then, the secondary antibody was removed and the membrane was washed two times for $5 \mathrm{~min}$ in TBS and $0.1 \%$ Tween 20 . The membranes were scanned in near-infrared spectroscopy (Odyssey Infrared Imaging System, LI-COR, Inc., Lincoln, NE, United States) with a resolution of $84 \mu \mathrm{M}$ and analyzed with Image Studio ${ }^{\mathrm{TM}}$ software (LI-COR, Inc., Lincoln, NE, United States) obtaining the values of integrated optical density of each band. The $\alpha$-tubulin content in each sample was used as a loading control.

\section{Confocal Microscopy}

A tissue culture coverslip (Sarstedt, Germany) was placed into wells of 24-well plates. In total, 25,000 PANC-1 cells were seeded in each well and allowed to grow for $24 \mathrm{~h}$. Then, the cells were transfected with the plasmid ptfLC3 (Kimura et al., 2007) (following Lipofectamine instructions), and after $24 \mathrm{~h}$, TGM4 (35 $\mu \mathrm{M})$ was added to the medium for $48 \mathrm{~h}$. Cells were fixed with $4 \%(\mathrm{w} / \mathrm{v})$ paraformaldehyde (SigmaAldrich, St. Louis; MO, United States) in PBS for $15 \mathrm{~min}$ and washed with PBS. Cells were permeabilized using Triton $\mathrm{X}-1000,1 \%$ for $10 \mathrm{~min}$ and washed with PBS. Finally, to avoid background usually due to autofluorescence, cells were incubated for $10 \mathrm{~min}$ with $\mathrm{NH}_{4} \mathrm{Cl} 100 \mathrm{mM}$. The coverslips with the fixed cells were stained with DAPI (Sigma-Aldrich, St. Louis, MO. United States) (1:500 in PBS for $5 \mathrm{~min}$ in darkness). Slides and coverslips were mounted together using VECTASHIELD HardSet Antifade Mounting Medium (Vector Laboratories, United States), allowing them to dry for $24 \mathrm{~h}$ in darkness and then storing the slides at $4^{\circ} \mathrm{C}$ and darkness until the analysis. Slides were observed under a confocal microscopy at $63 \times$ augments (Leica Microsystems, Wetzlar, Germany), and different pictures were collected whereas the samples were excited by the appropriate laser at the determined wavelength to be analyzed. In this experiment, cells were transfected with ptfLC3. This plasmid contains both red and green fluorescent proteins (RFP and GFP) tagged to the light chain 3 (LC3) protein. In autophagosomes, there will be yellow signals (overlap of red and green fluorescence) whereas autolysosomes appear with red fluorescent LC3 due to degradation of the GFP.

\section{Peroxisome Proliferator-Activated Receptor Gamma Activity}

In total, 50,000 PANC-1 cells were seeded in 12-well plates. UAS-E1BTATA-LUC reporter and pRL-SV40P Renilla plasmids were cotransfected with the plasmid encoding the ligandbinding domain of peroxisome proliferator-activated receptor gamma (PPAR- $\gamma$ ) (Gal4-PPARGLB) following lipofectamine 2000 instructions (Park et al., 2003). After 24 h of transfection, cells were treated for $48 \mathrm{~h}$ with TGM4 at doses of 15, 25, and $35 \mu \mathrm{M}$. Rosiglitazone was used as positive control. Then, cells were subjected to dual-luciferase assay (Promega) following manufacturer's instructions. Renilla expression values that are used as an internal control (Sherf et al., 1996). PPAR- $\gamma$ activity (first lecture)/Renilla level (second lecture) ratios were used to analyze the results.

\section{In vivo Studies: Human Pancreatic Carcinoma Cells Xenograft Mice Model}

NUDE mice [Swiss Crl:NU (Ico)-Foxn1 nu; Charles River Laboratories, France], aged between 4 and 6 weeks and with approximately $25 \mathrm{~g}$ of weight, were used. These animals were maintained under sterile conditions, kept on plastic cages located in a sterile closet (EHRET, Labor_U_Pharmatechnik, Deutschland) with a constant temperature of $28^{\circ} \mathrm{C}$. The cabinet was kept in a room with a 12-h light/12-h dark schedule and a relative humidity of $40-60 \%$. All the work or manipulation of the animals was conducted in every moment under sterile conditions on BSL-2 flow cabinets.

To study the in vivo effect of TGM4, a xenotransplant model was used. The cell line Mia-PaCa-2 was expanded and washed with PBS, and the trypsinized cells were collected in DMEM medium. Viable cells were counted and centrifuged at $600 \times g$ for $5 \mathrm{~min}$ and resuspended in DMEM medium without FBS, to avoid immune reactions. A total of $7.5 \times 10^{6}$ cells were injected subcutaneously with a $25-\mathrm{G}$ caliber needle, in a volume of $150 \mu \mathrm{l}$. One week after inoculation, the tumors had approximated size of $5 \mathrm{~mm}$ and the treatment began.

The tumors size was measured once a week with a digital caliper. The tumor volumes were calculated by the formula: volume $\left(\mathrm{mm}^{3}\right)=(2 \mathrm{~W} \times \mathrm{L}) / 2$, where $\mathrm{W}$ represents the width and $\mathrm{L}$ represents the length of the tumor.

Animals' treatments: To investigate the in vivo efficacy of TGM4, the animals were divided into three groups: treated with TGM4, gemcitabine, and control animals. A total of eight animals (four males and four females) were used for each condition. The treated animals received daily $1,000 \mathrm{mg} / \mathrm{kg}$ of TGM4 by cannulation. The control animals received nothing or $100 \mathrm{mg} / \mathrm{kg}$ of gemcitabine two times a week. Gemcitabine is the standard of care for the treatment of pancreatic cancer, and it was administrated through intraperitoneal injection. Oral administration is preferred since molecules are subjected to the processes of digestion and absorption. However, gemcitabine was given intraperitoneally since oral bioavailability is only $10 \%$ due to low intestinal permeability and oral absorption (Thompson et al., 2019). The duration of the experiment was 43 days. After the treatments, the animals were euthanized by decapitation.

All the protocols and procedures were revised and approved by the Comité Institucional de Investigación Animal (Comisión de Bioética de la Universitat de les Illes Balears). Project authorization was granted on 2018 by the Institutional Committee for Animal Research of the Balearic Government under the protocol number CEEA 94/05/18 (2018/09/AEXP).

\section{Data Analysis}

All data shown in the graphs correspond to the mean values \pm standard error of the mean (SEM) of at least three independent in vitro experiments (each duplicated) or cellular experiments. For animal studies, there is indicated in the graphs the number of animals used $(N)$. The statistical analysis 

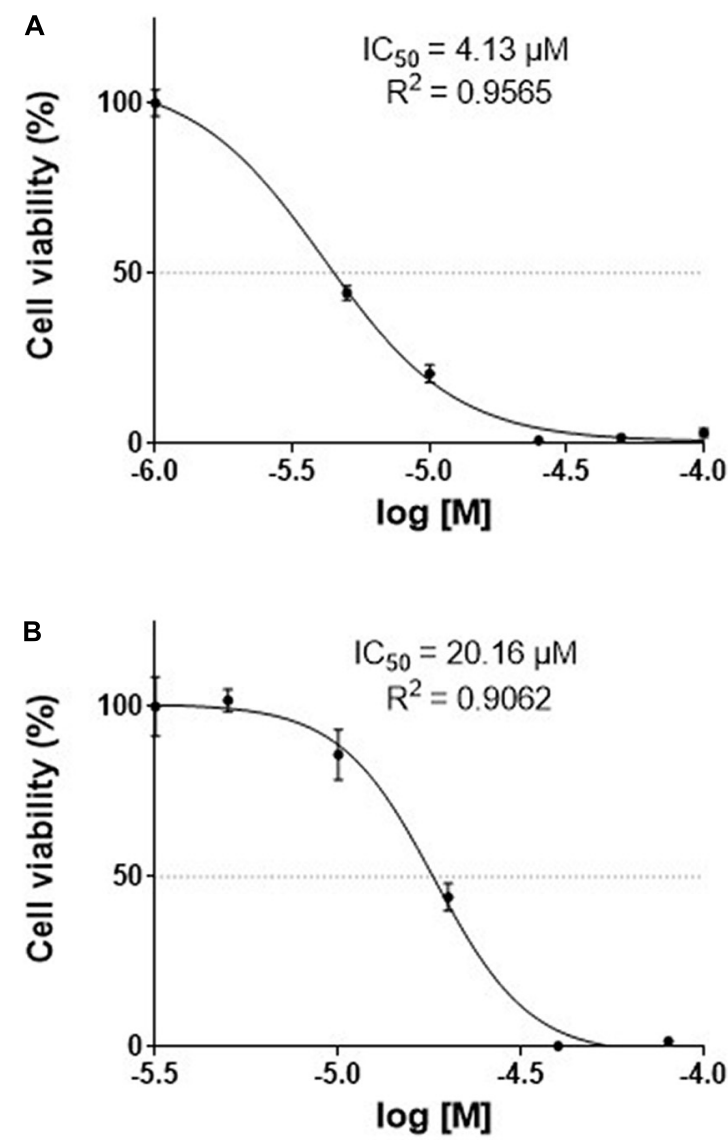

FIGURE 2 | Effects of TGM4 on the proliferation of Mia-PaCa-2 (A) and PANC-1 (B) human pancreatic cell lines. Mia-PaCa-2 and PANC-1 were exposed to increasing doses (50-1000 $\mu \mathrm{M})$ of TGM4 for $72 \mathrm{~h}$, and cell viability was determined using the XTT method $(n=12)$. The $\mathrm{IC}_{50}$ values for TGM4 in Mia-PaCa-2 and PANC-1 were 20.16 and $4.13 \mu \mathrm{M}$, respectively.

was performed by the average Student's $t$-test, configured as unpaired, two-tailed test, with confidence intervals of 95\%. For the statistical analysis of the animal studies, the nonparametric Mann-Whitney $U$ test was used. All statistical analyses were performed using GraphPad Prism 5.0 program. The differences between experimental groups were considered statistically significant at $p<0.5$. The different significances were represented as follows: ${ }^{*} p<0.05,{ }^{* *} p<0.01,{ }^{* * *} p<0.001$.

\section{RESULTS}

\section{Tri-2-Hydroxyarachidonein Impairs Cell Proliferation and Viability of Human Pancreatic Carcinoma and Human Pancreatic Carcinoma of Ductal Cell Lines}

Human pancreatic carcinoma and human pancreatic carcinoma of ductal cells were treated with different concentrations of TGM4, and cell death was measured by the XTT assay based on

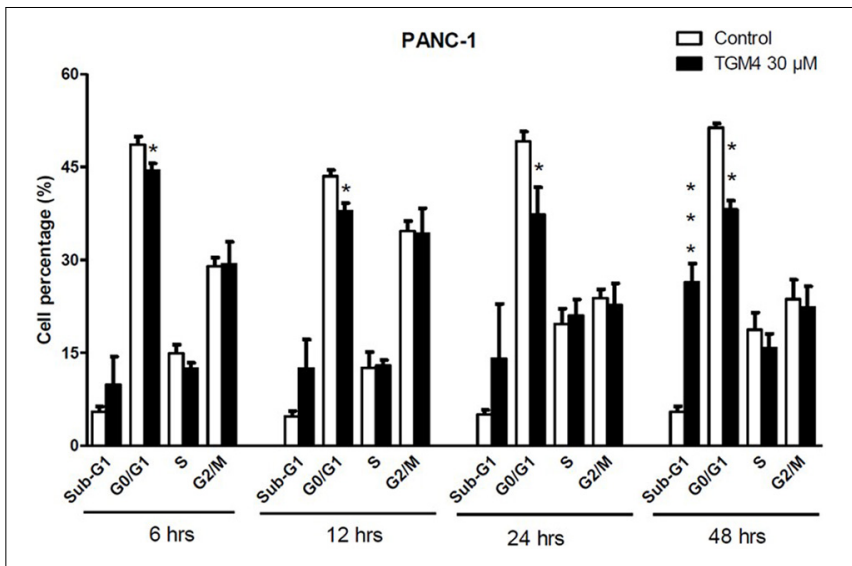

FIGURE 3 | Tri-2-hydroxyarachidonein induction of sub-G1 and cell cycle arrest at G0/G1 of PANC-1 human pancreatic cells. Analysis of the DNA content (flow cytometry) of PANC-1 cells exposed to TGM4 (30 $\mu \mathrm{M}$ for 6,12 , 24 , and 48 h) showing the proportion of cells in the cell cycle phases. Data represented as mean \pm SEM $(n=3)$. Statistical significance was determined by unpaired two-tailed Student's $t$-test $\left({ }^{\star} p<0.05 ;{ }^{\star *} p<0.01\right.$; ${ }^{\star * *} p<0.001$ ).

the mitochondrial function (succinate dehydrogenase activity). We observed that TGM4 (1-250 $\mu \mathrm{M} ; 72 \mathrm{~h})$ significantly impaired the growth of both PANC-1 $\left(\mathrm{IC}_{50}=4.13 \mu \mathrm{M} ; R^{2}=0.9565\right.$; Figure 2A) and Mia-PaCa-2 $\left(\mathrm{IC}_{50}=20.16 \mu \mathrm{M} ; R^{2}=0.9062\right.$; Figure 2B) human pancreatic cell lines.

\section{Tri-2-Hydroxyarachidonein Induces Cell Death in Human Pancreatic Carcinoma of Ductal Cells}

The proportion of cells in the different phases of the cell cycle was evaluated by measuring the intracellular DNA content after exposure to TGM4 (30 $\mu \mathrm{M} ; 6,12,24$, and $48 \mathrm{~h})$. TGM4 treatment lowered the proportion of cells in the G0/G1 when compared to untreated controls as early as after $6 \mathrm{~h}$ of treatment (Figure 3) being the maximum observed after $48 \mathrm{~h}$ of treatment (control, $51.35 \pm 0.65 \%$; TGM4, $38.12 \pm 1.42 \%$, $p<0.01$ ). On the other hand, after $48 \mathrm{~h}$ of treatment, TGM4 produced a significant increase in the sub-G0 values (control, $5.47 \pm 0.90 \%$; TGM4, $26.33 \pm 3.05 \%, p<0.001)$ when compared to untreated cells indicating DNA fragmentation and cell death. No significant differences in S and G2/M phases were observed during TGM4 exposure.

\section{Tri-2-Hydroxyarachidonein Induces Reticular Stress and Autophagy}

As shown in Figure 3, the presence of the sub-G0 events after the exposure of PANC-1 cells to TGM4 indicates DNA damage and cell death. This feature was paralleled by the downregulation of PARP and upregulation of CHOP as shown in Figure 4. PARP is a $116 \mathrm{kDa}$ nuclear polymerase, which can be cleaved by many caspases. Cleavage of PARP promotes cell death and is used as a marker of cells undergoing apoptosis (Oliver et al., 1998). CHOP is a protein which expression is induced by ER stress and is able to suppress cell cycle progression from G1 to $S$ phase 


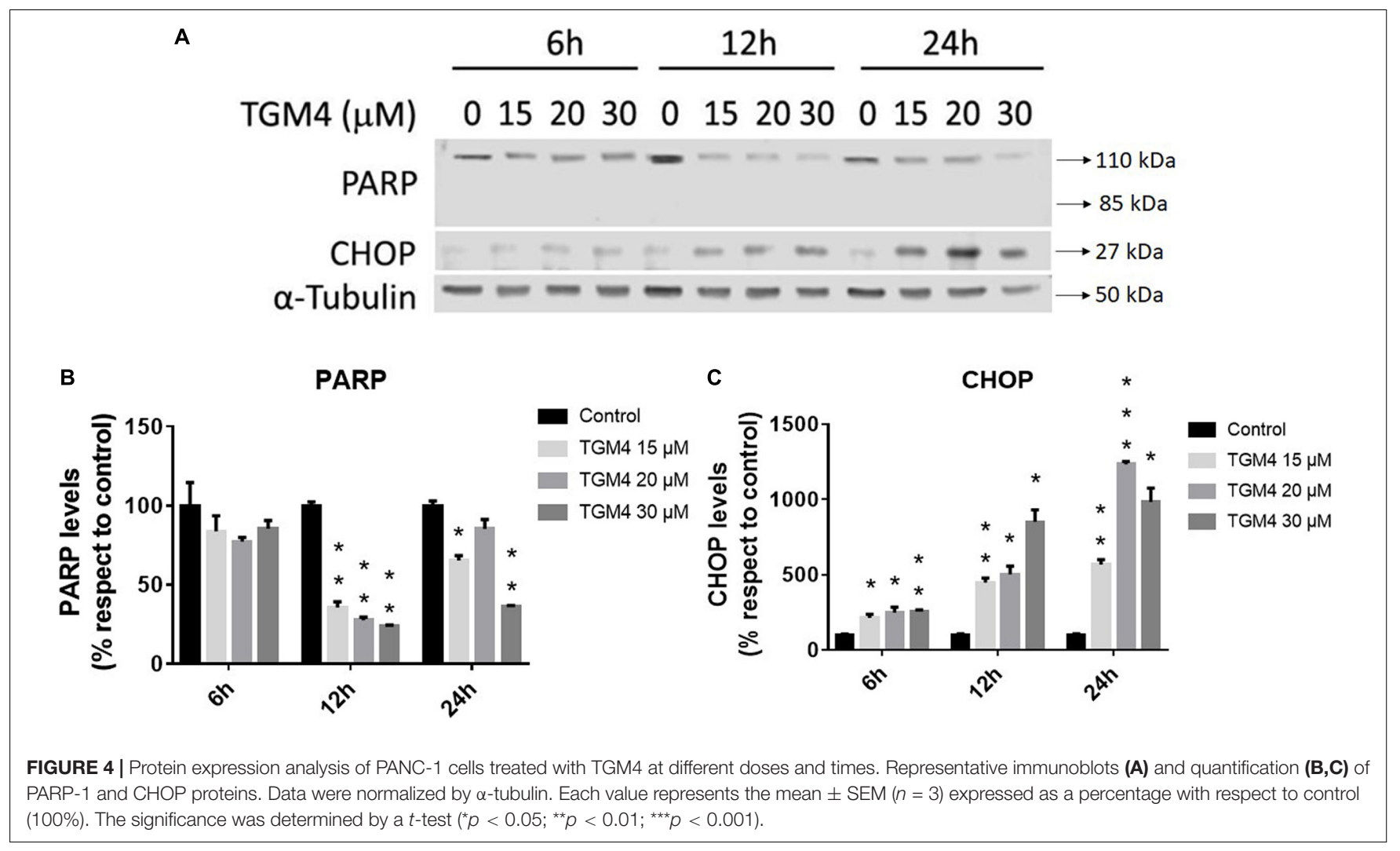

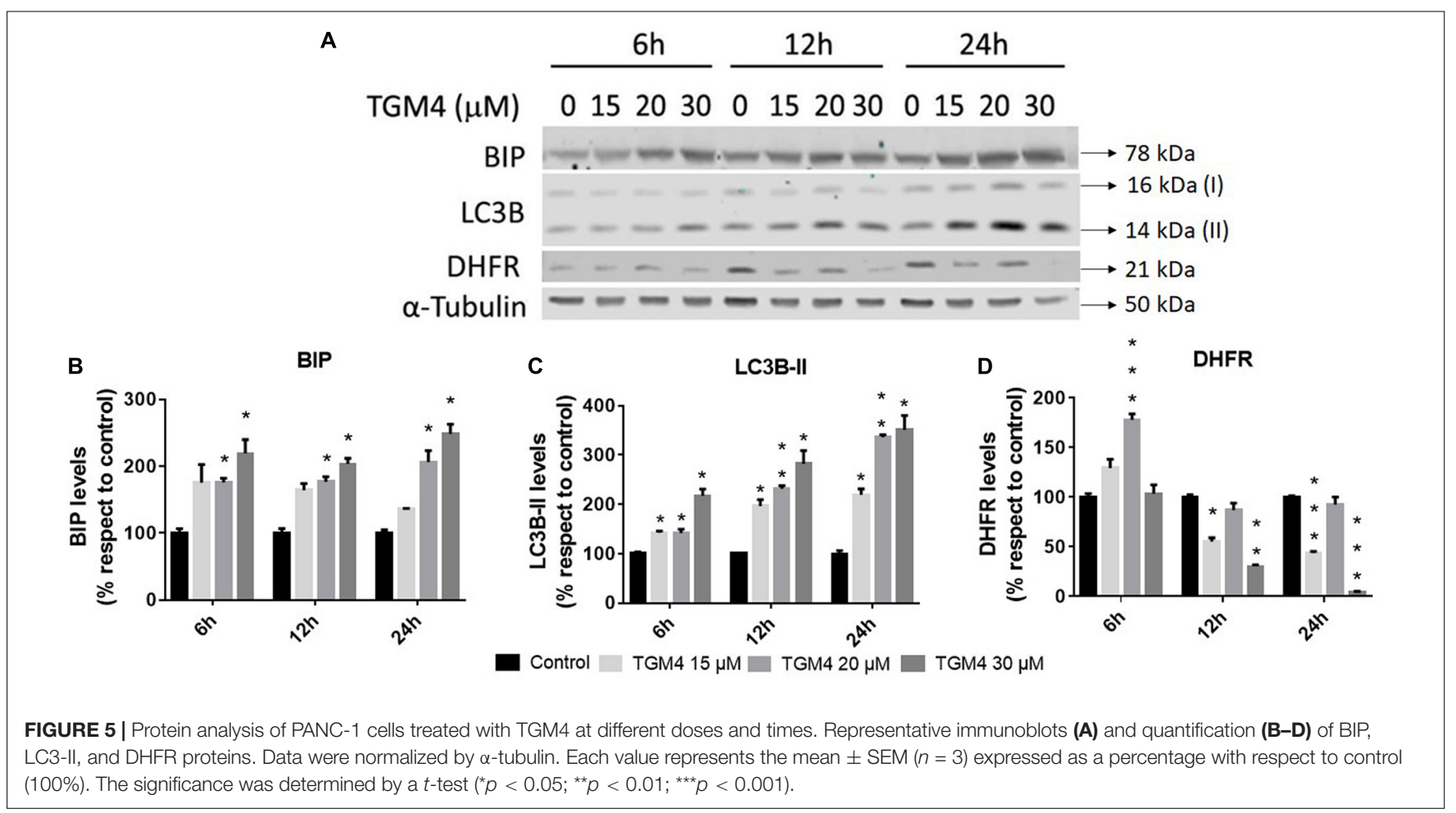

(Barone et al., 1994). PARP decreased after $12 \mathrm{~h}$ of treatment with $30 \mu \mathrm{M}$ TGM4 from $100 \pm 2.44 \%$ in controls to $23.92 \pm 0.70 \%$ $(p<0.01)$, whereas CHOP was increased from $100 \pm 8.70$ to
$850.24 \pm 80.79 \%(p<0.01)$. Although the fragmentation of PARP, a typical indicator of apoptosis, was not observed in our experiments, there was a loss of the full form of PARP as soon 

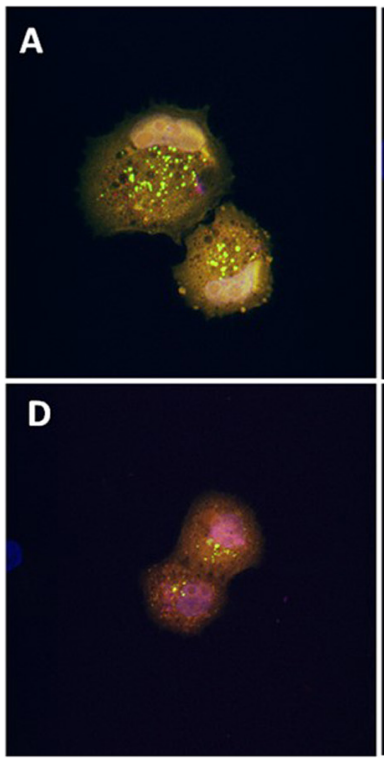
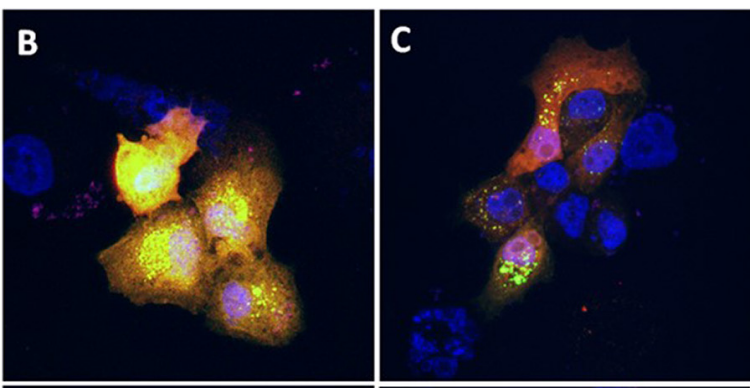

E
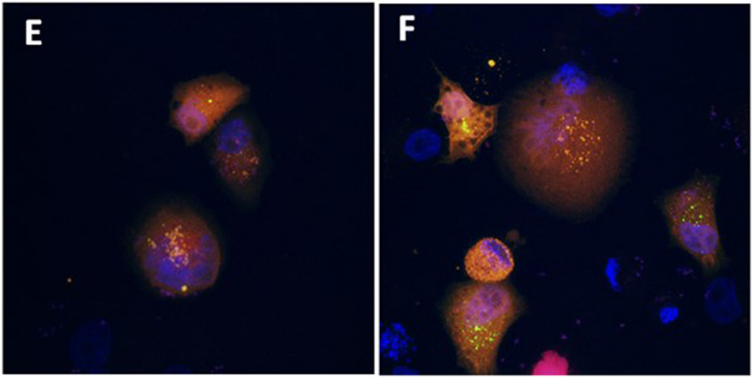

FIGURE 6 | Evaluation of the effect of TGM4 on autophagic flux. Representative confocal microscopy images (630 $\times$ ) of PANC-1 cells transfected with the ptfLC3 (LC3-RFP-GFP) plasmid and incubated with vehicle (A-C) or TGM4 $35 \mu \mathrm{M}$ (D-F) for $48 \mathrm{~h}$. Blue fluorescent signal (DAPI) marks the nucleus, whereas red and green signals represent LC3-B. After fusion of the autophagosome with lysosomes, green signal is degraded but not the red signal, due to differences in the isoelectric point between them.

as $6 \mathrm{~h}$ after TGM4 treatment which also is indicative of cell death processes (Tempka et al., 2018). On the other hand, TGM4 treatment upregulated $\mathrm{CHOP}$ as soon after $6 \mathrm{~h}$ of treatment (Figure 4). CHOP upregulation initiates apoptotic cells ( $\mathrm{Hu}$ et al., 2019). Since CHOP upregulation is marking endothelial reticulum-induced cell death, we next studied whether TGM4 induced the expression of BIP as well, a key marker of endothelial reticulum stress. Indeed, treatment of PANC-1 cells with TGM4 (30 $\mu \mathrm{M})$ upregulated BIP expression (Figure 5). The protein levels of BIP were increased after $12 \mathrm{~h}$ of treatment from $100 \pm 6.98 \%$ in control untreated cells to $203.32 \pm 8.47 \%$ $(p<0.01)$. We next studied whether TGM4 treatment had activity in regulating other ER or autophagy markers as LC3B and DHFR. As can be seen in Figure 5, the bottom fragment of LC3B (LC3B-II) is upregulated as well after TGM4 treatment in a time- and dose-dependent manner. LC3B-II levels were increased after $12 \mathrm{~h}$ of treatment with $30 \mu \mathrm{M}$ of TGM4 from $100 \pm 1.48$ to $282.12 \pm 26.81 \%(p<0.05)$ indicating an increase in autophagic flux. In this line of evidence, a representative example of the autophagic flux increase by TGM4 can be observed in Figure 6. Control PANC-1 cells (Figures 6A-C) showed more autophagosomes not fused with lysosomes (yellow and green signals) compared with PANC-1 cells treated with TGM4 (Figures 6B-D) were more autolysosomes (red signals; the fusion of the autophagosomes with lysosomes results in the degradation of GFP but not RFP producing red fluorescence) are observed. This result is further supported by the loss of DHFR (Figure 5). DHFR levels were decreased after $12 \mathrm{~h}$ of treatment with $30 \mu \mathrm{M}$ of TGM4 from $100 \pm 2.56$ to $30.19 \pm 1.57 \%$ $(p<0.01)$, which is also a marker of autophagic flux increase (Salvador et al., 2000; Majeski and Dice, 2004).
AKT and Jun are two oncogenes involved in proliferation and apoptosis and also mediate autophagy and tumorigenesis through the phosphorylation of a number of targets (Wang et al., 2012; Zhu et al., 2017). As observed in Figure 7, the ratio p-cJun/Jun decreased after $12 \mathrm{~h}$ of treatment with $30 \mu \mathrm{M}$ of TGM4 from $100 \pm 2.43$ to $76.75 \pm 1.17 \%(p<0.05)$ whereas the ratio p-Akt/Akt increased after $12 \mathrm{~h}$ of treatment with $30 \mu \mathrm{M}$ of TGM4 from $100 \pm 6.103$ to $138.59 \pm 4.04 \%(p<0.05)$.

\section{Tri-2-Hydroxyarachidonein Induces Peroxisome Proliferator-Activated Receptor Gamma Activation}

It has been shown that arachidonic acid induces PPAR- $\gamma$ activity (Kliewer et al., 1997), and in turn, PPAR- $\gamma$ activation can induce autophagy (Soto-Avellaneda and Morrison, 2020). To further explore the cellular mechanism that explains the cytocidal autophagy induced by TGM4, we studied whether TGM4 was able to induce PPAR- $\gamma$ activity. As is shown in Figure 8, TGM4 was able to induce the activity of PPAR- $\gamma$ in the same range as rosiglitazone, a well-known PPAR- $\gamma$ activator. PPAR- $\gamma$ activity levels were increased from $595 \pm 66.1$ to $1251 \pm 126.6(p<0.01)$; $1075 \pm 151.7(p<0.05) ; 1311 \pm 132.4(p<0.01)$ after $48 \mathrm{~h}$ of treatment with TGM4 at doses of 15,25 , and $35 \mu \mathrm{M}$, respectively.

\section{Tri-2-Hydroxyarachidonein Effect on the Progression of Human Pancreatic Carcinoma Cell Line Xenograft in Nude Immunodepressed Mice}

Finally, the TGM4 antitumor activity was tested in vivo on a xenograft mice model. The tumor was induced by subcutaneous 


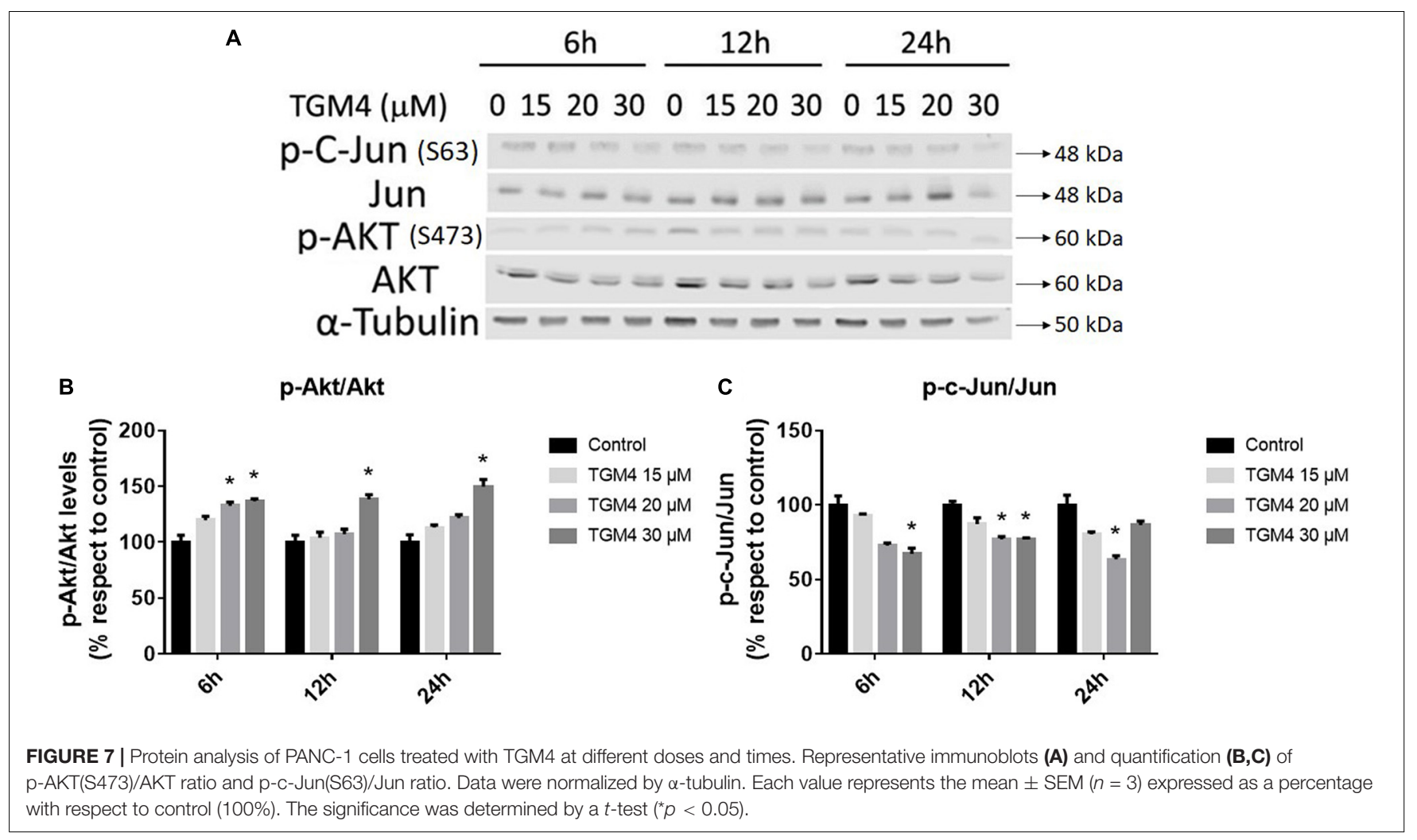

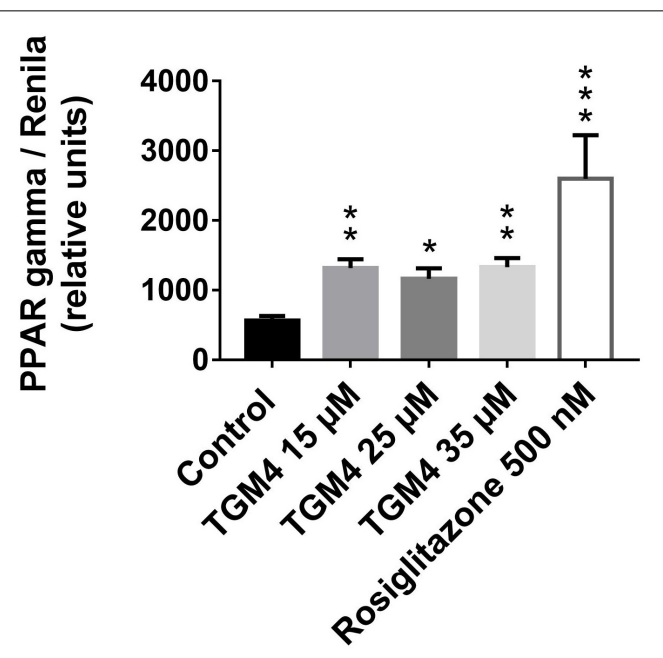

FIGURE 8 | Effect of different doses of TGM4 on the activity of PPAR- $\gamma$ on PANC-1 cells. PANC-1 cells were treated with 15,25 , and $35 \mu \mathrm{M}$ of TGM4. PPAR $-\gamma$ modulation was evaluated by the quantification of luciferase signal that is induced by PPAR- $\gamma$ activity. Rosiglitazone (ROS) $500 \mathrm{nM}$ was used as a positive control. The values were determined by luminescence measurement, and the mean \pm SEM of 2 independent experiments with 3 replicates each expressed as a percentage with respect to the control were represented. The significance was determined by a $t$-test $\left({ }^{\star} p<0.05 ;{ }^{* *} p<0.01 ;{ }^{* \star *} p<0.001\right.$ ).

injection of $7.5 \times 106 \mathrm{Mia}-\mathrm{PaCa}-2$ cells per mouse. TGM4 was administrated orally and daily at a dose of $1,000 \mathrm{mg} / \mathrm{kg}$ of body weight. Control mice received nothing or gemcitabine
$100 \mathrm{mg} / \mathrm{kg}$ i.p. two times a week, the standard of care for the treatment of pancreatic cancer. The experiment lasted for 43 days, during which the tumor volume was measured. After 43 days of treatment, the average size of the tumors of nontreated animals was $1269.58 \pm 227.74 \mathrm{~mm}^{3}$ whereas the average size of the tumors of animals treated with gemcitabine or TGM4 was $302.60 \pm 148.36$ and $314.57 \pm 95.38$, respectively $(p<0.001)$ (Figure 9).

\section{DISCUSSION}

An intricate network of signaling pathways governs pancreatic cancer progression (Polireddy and Chen, 2016). In fact, pancreatic cancer demonstrated hundreds of chromosomal structural variants per patient (Jones et al., 2008; Waddell et al., 2015). Unfortunately, because of this complex landscape, there are no effective therapies available to date, and novel conceptual approaches are needed. Among these novel approaches, the use of synthetic lipid molecules to interfere with the proliferative events of cancer cells is indeed worth to be investigated.

During the past decades, it has been demonstrated a lipid metabolic reprogramming in cancer cells (Fernández et al., 2020) and that the proportion of membrane lipid species is altered in a number of tumors including pancreatic cancer (Meng et al., 2004; Casares et al., 2019).

As classical examples of the role of lipid molecules in the cancer cell fate, it is well known that ceramides play a major role in the regulation of apoptosis (Riboni et al., 2002) 


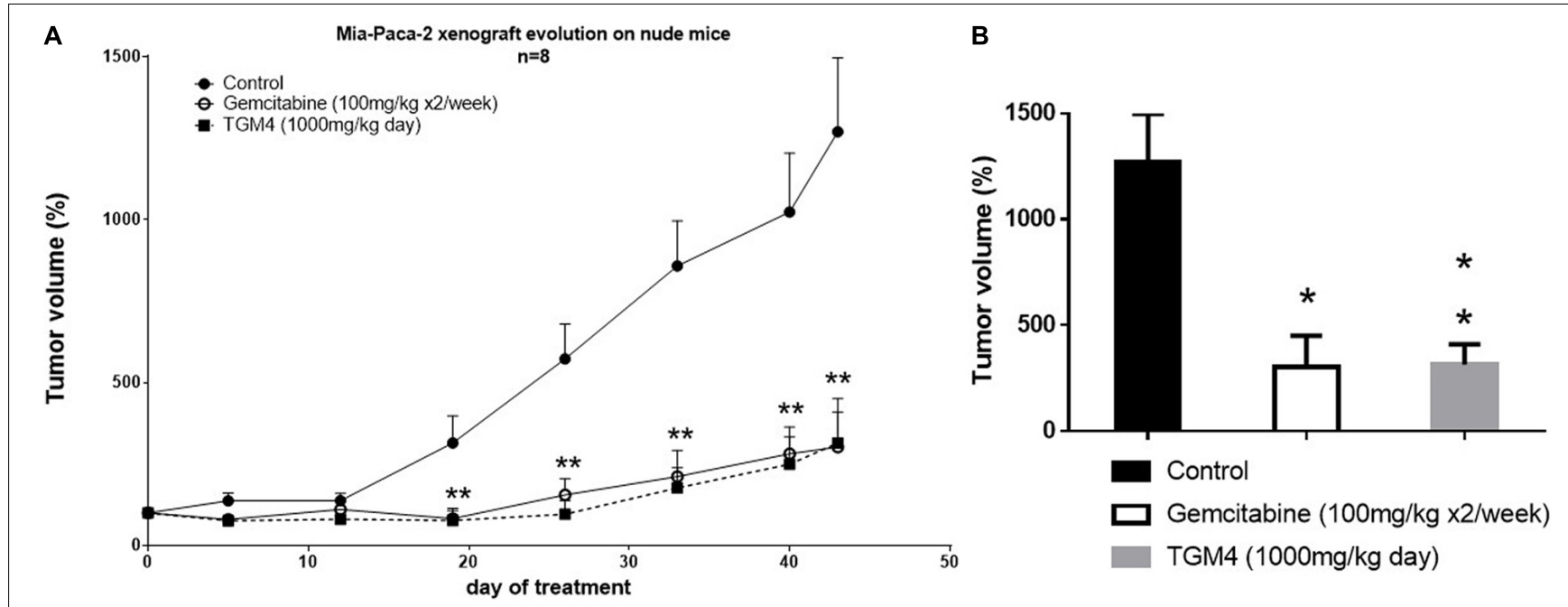

FIGURE 9 | Effect of TGM4 in xenograft model of pancreatic cancer (Mia-PaCa-2). A total of $7.5 \times 106$ Mia-PaCa-2 were injected subcutaneously in immunosuppressed nude Swiss Crl: NU (ICO) - Foxn1nu mice. Control animals received nothing or subcutaneous injections of 100 mg/kg of gemcitabine two times a week. The treated animals received through cannulation $1,000 \mathrm{mg} / \mathrm{Kg}$ of TGM4. (A) Changes in the tumors volumes through 43 days of treatment represented as percentage respect day 0. Significance indicates TGM4 against control. (B) Percentage of tumors volumes at day 43 of treatment. Each value represents the average of the percentages $\pm \operatorname{SEM}(n=8)$ relative to day 0 (taken as $100 \%)$; non-parametric Mann-Whitney $U$ test $\left({ }^{\star} p<0.05\right.$; $\left.{ }^{* \star} p<0.01\right)$.

and that glycosphingolipid species aberrantly expressed in tumors (Hettmer et al., 2005) induce angiogenesis (Birklé et al., 2003). In this conceptual frame, our group demonstrated that sphingomyelin synthase 1 and sphingomyelin synthase 2 showed opposite associations with the survival of patient with glioma (Fernández-García et al., 2019). Recently, we proved that the use of synthetic lipid molecules can indeed change the cell signaling events associated with a variety of cancers. In this regard, we demonstrated that the synthetic fatty acid 2-hydroxyoleic acid induced cytotoxic autophagy in glioma cells lines and in human glioma animal models (MarcillaEtxenike et al., 2012; Teres et al., 2012; Beteta-Göbel et al., 2021). In fact, 2-hydroxyoleic acid is currently in a phase IIB/III randomized, double-blind, placebo-controlled trial in subjects with newly diagnosed primary glioblastoma multiforme (NCT04250922) and in an open-label, non-randomized study in pediatric patients with advanced high-grade gliomas and other solid tumors (NCT04299191).

Previous work of our group also showed that hydroxytriolein has an antitumor efficacy against non-small cell lung cancer (NSCLC). Hydroxytiolein is a synthetic 2-hydroxy fatty-acyl triolein derivative that induces the membrane translocation and activation of PKC and ERK, and also the production of reactive oxygen species and macroautophagy (Guardiola-Serrano et al., 2015).

Now, we investigated a synthetic lipid termed TGM4, based on the structure of the synthetic lipid 2-hydroxy-arachidonic acid with the aim to induce cytotoxic autophagy in pancreatic tumor cell lines. The rationale behind the synthesis of TGM4 is that arachidonic acid is able to induce autophagy in a variety of cell types (O'Rourke et al., 2013). Our in vitro studies clearly showed that TGM4 decreases the number of viable pancreatic tumor cells (Mia-PaCa-2 and PANC-1) in a time- and concentration-dependent manner (Figure 2). These results were paralleled by an increase of sub-G0 population events (Figure 3) indicating the induction of cell death by TGM4. In this regard, PARP expression and fragmentation were analyzed as an indicator of apoptosis. As shown in Figure 4, fragmentation of PARP was not observed after treatment with TGM4 but a downregulation of full-length PARP $(116 \mathrm{kDa})$ which may mark cell death since downregulation of full-size PARP protein results also in DNA damage and decreased viability (Tempka et al., 2018). In addition, TGM4 treatment induced CHOP upregulation (Figure 4) a well-known marker and initiator of apoptotic cell death if endothelial reticulum homeostasis is not restored (Hu et al., 2019). CHOP is considered the link between endothelial reticulum stress and autophagy (B'chir et al., 2014). Under endothelial stress conditions, CHOP promotes IRE1 $\alpha$ signaling pathway activation and autophagy (Shimodaira et al., 2014). Moreover, the upregulation of CHOP by TGM4 was paralleled by the upregulation of BIP (Figure 5), and one of the master regulators of the UPR/autophagy and represents a pharmaceutical target to induce autophagy and apoptosis in melanoma cancer cells (Cerezoa and Rocchib, 2017).

The aggregation and posttranscriptional modification of microtubule-associated protein LC3, a mammalian homolog of yeast Atg8, has been also used as a specific marker to monitor autophagy (Kuma et al., 2007). LC3B is first cleaved at the carboxy terminus immediately following synthesis to yield a cytosolic form LC3B-I. During autophagy, LC3B-I is converted to LC3B-II by a ubiquitin-like system involving Apg7 and Apg3 that allows for LC3 to become associated with autophagic vesicles (Ichimura et al., 2000; Kabeya et al., 2000; He et al., 2003; Tanida et al., 2004; Wu et al., 2006). As shown in Figure 5, TGM4 induced a marked overexpression of LC3B-II suggesting an increase in the autophagic flux 
(Figure 6) and consequently that autophagy is triggered after TGM4 treatment. In addition to the overexpression of LC3BII, the use of the plasmid that expresses LC3B tagged with RFP and GFP allowed us to confirm, after treatment with TGM4, the fusion of the autophagosomes with the lysosomes and the consequent formation of autolysosomes. The low $\mathrm{pH}$ of the autolysosomes degrades the green signal while not altering red signal due to differences in the isoelectric point of both fluorescent proteins. In this line of evidence, the downregulation of DHFR (Figure 5) also argues in favor of autophagy and autophagosome activity since degradation of DHFR occurs in autophagosomes. In fact, DHFR has been used to investigate the uptake of cytosolic proteins into lysosomes for degradation by the chaperone-mediated autophagic pathway (Salvador et al., 2000; Majeski and Dice, 2004). Moreover, downregulation of DHFR by the synthetic fatty acid HOA hampers glioma and leukemia cancer cells replication (Lladó et al., 2009).

Among the lipids that induce autophagy, the role of $\omega-6$ polyunsaturated fatty acids is remarkable (O'Rourke et al., 2013). In this regard, supplementation with arachidonic acid and di-homo- $\gamma$-linoleic acid leads to the increase of autophagic marker LC3-II in HeLa cells together with downregulation of p62 (O'Rourke et al., 2013). The formation of LC3 puncta in HeLa cells after treatment with arachidonic acid or DGLA is diminished by the inactivation of the autophagy gene ATG161L indicated the capacity of $\omega$ 6 PUFAs to activate the autophagic flux in HeLa cells (O’Rourke et al., 2013).

The cellular mechanisms that are responsible for the induction of cytocidal autophagy by TGM4 are unknown; however, our results on PPAR- $\gamma$ activation (Figure 8) suggest at least a partial role of the peroxisome proliferator-activating factors. These nuclear receptors which are activated by lipid signals control the expression of autophagy and autophagy-related genes (SotoAvellaneda and Morrison, 2020 and references therein).

Tri-2-hydroxyarachidonein has demonstrated to interfere with the PI3K/AKT and Jun pathways. As shown in Figure 7, TGM4 induced the upregulation of $\mathrm{p}$-AKT and downregulation of p-c-Jun as soon as $6 \mathrm{~h}$ after treatment. We hypothesize that these effects could be a part of a secondary survival cellular mechanism to counteract the activation of the endothelial reticulum and cell death pathways since Akt inhibition promotes autophagy (Degtyarev et al., 2008) and activation of JNK reduces autophagy and increases apoptosis providing a promising strategy for prostate cancer therapy (Zhu et al., 2017).

Finally, to validate the effects of TGM4 in organic tumors, we used a nude immunodepressed mice model. As shown in Figure 9, the effect of the TGM4 at a daily oral dose of $1,000 \mathrm{mg} / \mathrm{kg}$ is very similar to that produced by the drug of reference gemcitabine at a dose of $100 \mathrm{mg} / \mathrm{kg}$ given to the mice by intraperitoneal injection two times a week.

We demonstrated that TGM4 induces pancreatic cell death by the activation of autophagy and related signal transduction events in cell cultures and reduces tumor growth in an in vivo xenograft model. This work highlights the importance of lipid signaling in cancer and the use of synthetic lipid structures, as TGM4, as a novel approach to treat pancreatic cancer and other neoplasias.

\section{DATA AVAILABILITY STATEMENT}

The raw data supporting the conclusions of this article will be made available by the authors, without undue reservation.

\section{ETHICS STATEMENT}

The animal study was reviewed and approved by the Comité Institucional de Investigación Animal (Comisión de Bioética de la Universitat de les Illes Balears).

\section{AUTHOR CONTRIBUTIONS}

JF-D, RB-G, MT, JC, PF-G, VL, PE, and XB discussed the concepts, wrote the parts, and reviewed the entire manuscript. All authors contributed to the article and approved the submitted version.

\section{FUNDING}

This research was funded by grants from the Ministerio de Economía y Competitividad (PE: RTC-2015-3542, RTC2015-4094, and RTC2019-007399-1, cofinanced by FEDER funds) and by the Govern de les Illes Balears and European Social Fund (Grants ES01/TCAI/53_2016, PROCOE/5/2017, ES01/TCAI/21_2017, and ES01/TCAI/24_2018). This work was also supported in part by the European Commission (PE: H2020 Framework Programme Project CLINGLIO 755179). JF-D was supported by an Industry Doctorate from the Govern de les Illes Balears and European Social Fund (FPI/1981/2016). RB-G was supported by an Industry Doctorate contract from the Spanish Ministerio de Economía y Competitividad (DI-14-06701). JC was supported by an Industry Doctorate from the Govern de les Illes Balears and European Social Fund (FPI_063_2020). VL was a recipient of a Torres-Quevedo research contract from the Spanish Ministerio de Economía y Competitividad and the European Social Fund "Investing in your future" (PTQ-17-09056).

\section{ACKNOWLEDGMENTS}

We wish to thank Guillem Ramis, from the Cellomic Unit at the University of the Balearic Islands, for his help with the confocal microscopy imaging and flux cytometry technical support. The ptfLC3 plasmid used here was a generous gift from Tamotsu Yoshimori (Addgene plasmid \#21074; http:// n2t.net/addgene:21074; accessed on: January 30, 2018; RRID: Addgene_21074, Watertown, MA, United States). We also thank J. L. Jameson's team from the Division of Endocrinology, Metabolism, and Molecular. 


\section{REFERENCES}

Adachi, S., Yasuda, I., Kawaguchi, J., Yamauchi, T., Nakashima, M., Itani, M., et al. (2011). Ultraviolet enhances the sensitivity of pancreatic cancer cells to gemcitabine by activation of 5' AMP-activated protein kinase. Biochem. Biophys. Res. Commun. 414, 53-59. doi: 10.1016/j.bbrc.2011.09.020

Barone, M. V., Crozat, A., Tabaee, A., Philipson, L., and Ron, D. (1994). CHOP (GADD153) and its oncogenic variant, TLS-CHOP, have opposing effects on the induction of G1/S arrest. Genes Dev. 8, 453-464. doi: 10.1101/gad.8.4.453

B'chir, W., Chaveroux, C., Carraro, V., Averous, J., Maurin, A.-C., Jousse, C., et al. (2014). Dual role for CHOP in the crosstalk between autophagy and apoptosis to determine cell fate in response to amino acid deprivation. Cell. Signal. 26, 1385-1391. doi: 10.1016/j.cellsig.2014.03.009

Beteta-Göbel, R., Fernández-Díaz, J., Arbona-González, L., Rodríguez-Lorca, R., Torres, M., Busquets, X., et al. (2021). The Novel Antitumor Compound HCA Promotes Glioma Cell Death by Inducing Endoplasmic Reticulum Stress and Autophagy. Cancers 13:4290. doi: 10.3390/cancers13174290

Birklé, S., Zeng, G., Gao, L., Yu, R. K., and Aubry, J. (2003). Role of tumorassociated gangliosides in cancer progression. Biochimie 85, 455-463. doi: 10. 1016/s0300-9084(03)00006-3

Brenner, C., Galluzzi, L., Kepp, O., and Kroemer, G. (2013). Decoding cell death signals in liver inflammation. J. Hepatol. 59, 583-594. doi: 10.1016/j.jhep.2013. 03.033

Casares, D., Escribá, P. V., and Rosselló, C. A. (2019). Membrane Lipid Composition: effect on Membrane and Organelle Structure, Function and Compartmentalization and Therapeutic Avenues. Int. J. Mol. Sci. 20, 21672197. doi: 10.3390/ijms20092167

Cerezoa, M., and Rocchib, S. (2017). New anti-cancer molecules targeting HSPA5/BIP to induce endoplasmic reticulum stress, autophagy and apoptosis. Autophagy 13, 216-217. doi: 10.1080/15548627.2016.1246107

Degtyarev, M., Mazière, A. D., Orr, C., Lin, J., Lee, B. B., Tien, J. Y., et al. (2008). Akt inhibition promotes autophagy and sensitizes PTEN-null tumors to lysosomotropic agents. J. Cell. Biol. 183, 101-116. doi: 10.1083/jcb.200801099

Everhart, J., and Wright, D. (1995). Diabetes mellitus as a risk factor for pancreatic cancer. A meta-analysis. JAMA 273, 1605-1609.

Ferlay, J., Shin, H. R., Bray, F., Forman, D., Mathers, C., and Parkin, D. M. (2010). Estimates of worldwide burden of cancer in 2008: GLOBOCAN 2008. Int. J. Cancer 127, 2893-2917. doi: 10.1002/ijc.25516

Fernández, L. P., de Cedrón, M. G., and de Molina, A. R. (2020). Alterations of Lipid Metabolism in Cancer: implications in Prognosis and Treatment. Front. Oncol. 10:577420. doi: 10.3389/fonc.2020.57742

Fernández-García, P., Rosselló, C. A., Rodríguez-Lorca, R., Beteta-Göbel, R., Fernández-Díaz, J., Lladó, V., et al. (2019). The opposing contribution of SMS1 and SMS2 to glioma progression and their value in the therapeutic response to 2OHOA. Cancers 11:88. doi: 10.3390/cancers11010088

Gapstur, S. M., Gann, P. H., Lowe, W., Liu, K., Colangelo, L., and Dyer, A. (2000). Abnormal glucose metabolism and pancreatic cancer mortality. JAMA 283, 2552-2559. doi: 10.1001/jama.283.19.2552

Guardiola-Serrano, F., Beteta-Göbel, R., Rodríguez-Lorca, R., Ibarguren, M., López, D. J., Terés, S., et al. (2015). The novel anticancer drug hydroxytriolein inhibits lung cancer cell proliferation via a protein kinase $\mathrm{C} \alpha$ - and extracellular signal-regulated kinase 1/2-dependent mechanism. J. Pharmacol. Exp. Ther. 354, 213-224. doi: 10.1124/jpet.114.222281

He, H., Dang, Y., Dai, F., Guo, Z., Wu, J., She, X., et al. (2003). Post-translational modifications of three members of the human MAP1LC3 family and detection of a novel type of modification for MAP1LC3B. J. Biol. Chem. 278, 2927829287. doi: $10.1074 /$ jbc.M303800200

Hettmer, S., Ladisch, S., and Kaucic, K. (2005). Low complex ganglioside expression characterizes human neuroblastoma cell lines. Cancer Lett. 225, 141-149. doi: 10.1016/j.canlet.2004.11.036

Hu, H., Tian, M., Ding, C., and Yu, S. (2019). The C/EBP Homologous Protein (CHOP) Transcription Factor Functions in Endoplasmic Reticulum StressInduced Apoptosis and Microbial Infection. Front. Immunol. 9:3083. doi: 10. 3389/fimmu.2018.03083

Huxley, R., Ansary-Moghaddam, A., Berrington de González, A., Barzi, F., and Woodward, M. (2005). Type-II diabetes and pancreatic cancer: a meta-analysis of 36 studies. Br. J. Cancer 92, 2076-2083. doi: 10.1038/sj.bjc.6602619
Ichimura, Y., Kirisako, T., Takao, T., Satomi, Y., Shimonishi, Y., Ishihara, N., et al.(2000). A ubiquitin-like system mediates protein lipidation. Nature 408, 488-492. doi: $10.1038 / 35044114$

Jemal, A., Siegel, R., Ward, E., Hao, Y., Xu, J., and Thun, M. J. (2009). Cancer statistics. CA Cancer J. Clin. 59, 225-249. doi: 10.3322/caac.20006

Jones, S., Zhang, X., Parsons, D. W., Lin, J. C., Leary, R. J., Angenendt, P., et al. (2008). Core signaling pathways in human pancreatic cancers revealed by global genomic analyses. Science 321, 1801-1806. doi: 10.1126/science.1164368

Kabeya, Y., Mizushima, N., Ueno, T., Yamamoto, A., Kirisako, T., Noda, T., et al. (2000). LC3, a mammalian homologue of yeast Apg8p, is localized in autophagosome membranes after processing. EMBO J. 19, 5720-5728. doi: 10.1093/emboj/19.21.5720

Kimura, S., Noda, T., and Yoshimori, T. (2007). Dissection of the autophagosome maturation process by a novel reporter protein, tandem fluorescent-tagged LC3. Autophagy 5, 452-460. doi: 10.4161/auto.4451

Kliewer, S. A., Sundseth, S. S., Jones, S. A., Brown, P. J., Wisely, G. B., Koble, C. S., et al. (1997). Fatty acids and eicosanoids regulate gene expression through direct interactions with peroxisome proliferator-activated receptors $\alpha$ and $\gamma$. Proc. Natl. Acad. Sci. U. S. A. 94, 4318-4323. doi: 10.1073/pnas.94.9.4318

Kondo, Y., Kanzawa, T., Sawaya, R., and Kondo, S. (2005). The role of autophagy in cancer development and response to therapy. Nat. Rev. Cancer 5, 726-734. doi: $10.1038 /$ nrc1692

Kouroku, Y., Fujita, E., Tanida, I., Ueno, T., Isoai, A., Kumagai, H., et al. (2007). ER stress (PERK/eIF $\alpha$ phosphorylation) mediates the polyglutamine-induced LC3 conversion, an essential step for autophagy formation. Cell Death Differ. 14, 230-239. doi: 10.1038/sj.cdd.4401984

Kuhajda, F. P. (2006). Fatty acid synthase and cancer: new application of an old pathway. Cancer Res. 66, 5977-5980. doi: 10.1158/0008-5472.CAN-05-4673

Kuma, A., Matsui, M., and Mizushima, N. (2007). LC3, an autophagosome marker, can be incorporated into protein aggregates independent of autophagy: caution in the interpretation of LC3 localization. Autophagy 3, 323-328. doi: 10.4161/ auto. 4012

Lladó, V., Terés, S., Higuera, M., Alvarez, R., Noguera-Salva, M. A., Halver, J. E., et al. (2009). Pivotal role of dihydrofolate reductase knockdown in the anticancer activity of 2-hydroxyoleic acid. Proc. Natl. Acad. Sci. U. S. A. 106, 13754-13758. doi: 10.1073/pnas.0907300106

Lowry, O. H., Rosebrough, N. J., Farr, A. L., and Randall, R. J. (1951). Protein measurement with the Folin phenol reagent. J. Biol. Chem. 193, 265-275. doi: 10.1016/s0021-9258(19)52451-6

Majeski, A. E., and Dice, J. F. (2004). Mechanisms of chaperone-mediated autophagy. Int. J. Biochem. Cell. Biol. 36, 2435-2444. doi: 10.1016/j.biocel.2004. 02.013

Marcilla-Etxenike, A., Laura Martín, M. L., Noguera-Salvà, M. A., García-Verdugo, J. M., Soriano-Navarro, M., Dey, I., et al. (2012). 2-Hydroxyoleic acid induces ER stress and autophagy in various human glioma cell lines. PLoS One 7:e48235. doi: 10.1371/journal.pone.0048235

Martinet, W., Agostinis, P., Vanhoecke, B., Dewaele, M., and De Meyer, G. R. (2009). Autophagy in disease: a double-edged sword with therapeutic potential. Clin. Sci. 116, 697-712. doi: 10.1042/CS20080508

Meng, X., Riordan, N. H., Riordan, H. D., Mikirova, N., Jackson, J., González, M. J., et al. (2004). Cell membrane fatty acid composition differs between normal and malignant cell lines. P. R. Health Sci. J. 23, 103-106.

Michaud, D. S., Giovannucci, E., Willett, W. C., Colditz, G. A., Stampfer, M. J., and Fuchs, C. S. (2001). Physical activity, obesity, height, and the risk of pancreatic cancer. JAMA 286, 921-929. doi: 10.1001/jama.286.8.921

Miller, D. R., Cramer, S. D., and Thorburn, A. (2019). The interplay of autophagy and non-apoptotic cell death pathways. Int. Rev. Cell. Mol. Biol. 352, 159-187. doi: 10.1016/bs.ircmb.2019.12.004

Mizushima, N., Levine, B., Cuervo, A. M., and Klionsky, D. J. (2008). Autophagy fights disease through cellular self-digestion. Nature 451, 1069-1075. doi: 10. 1038/nature06639

Moenner, M., Pluquet, O., Bouchecareilh, M., and Chevet, E. (2007). Integrated endoplasmic reticulum stress responses in cancer. Cancer Res. 67, 10631-10634. doi: $10.1158 / 0008-5472$

Niso-Santano, M., Malik, S. A., Pietrocola, F., Bravo-San Pedro, J. M., Mariño, G., Cianfanelli, V., et al. (2015). Unsaturated fatty acids induce non-canonical autophagy. EMBO J. 34, 1025-1041. doi: 10.15252/embj.201489363 
Ogata, M., Hino, S. I., Saito, A., Morikawa, K., Kondo, S., Kanemoto, S., et al. (2006). Autophagy is activated for cell survival after endoplasmic reticulum stress. Mol. Cell Biol. 26, 9220-9231. doi: 10.1128/MCB.01453-06

Oliver, F. J., de la Rubia, G., Rolli, V., Ruiz-Ruiz, M. C., de Murcia, G., and Murcia, J. M. (1998). Importance of poly(ADP-ribose) polymerase and its cleavage in apoptosis. Lesson from an uncleavable mutant. J. Biol. Chem. 273, 33533-33539. doi: $10.1074 /$ jbc. 273.50 .33533

O’Rourke, E. J., Kuballa, P., Xavier, R., and Ruvkun, G. (2013). w-6 Polyunsaturated fatty acids extend life span through the activation of autophagy. Genes Dev. 27, 429-440. doi: 10.1101/gad.205294.112

Park, Y., Freedman, B. D., Lee, E. J., Park, S., and Jameson, J. L. (2003). A dominant negative PPAR $\gamma$ mutant shows altered cofactor recruitment and inhibits adipogenesis in 3T3-L1 cells. Diabetologia 46, 365-377. doi: 10.1007/ s00125-003-1037-4

Piffoux, M., Eriau, E., and Cassier, P. A. (2021). Autophagy as a therapeutic target in pancreatic cancer. Br. J. Cancer 124, 333-344. doi: 10.1038/s41416-020-01039-5

Polireddy, K., and Chen, Q. (2016). Cancer of the Pancreas: molecular Pathways and Current Advancement in Treatment. J. Cancer 7, 1497-1514. doi: 10.7150/ jca. 14922

Riboni, L., Campanella, R., Bassi, R., Villani, R., Gaini, S. M., Martinelli-Boneschi, F., et al. (2002). Ceramide levels are inversely associated with malignant progression of human glial tumors. Glia 39, 105-113. doi: 10.1002/glia.10087

Roth, M. T., Cardin, D. B., and Berlin, J. D. (2020). Recent advances in the treatment of pancreatic cáncer. F1000Res. 9:F1000FacultyRev-131. doi: 10. 12688/f1000research.21981.1

Saha, A. K., and Ruderman, N. B. (2003). Malonyl-CoA and AMP-activated protein kinase: an expanding partnership. Mol. Cell. Biochem. 253, 65-70. doi: 10.1023/ a:1026053302036

Salvador, N., Aguado, C., Horst, M., and Knecht, E. (2000). Import of a cytosolic protein into lysosomes by chaperone-mediated autophagy depends on its folding state. J. Biol Chem. 275, 27447-27456. doi: 10.1074/jbc.M001394200

Sherf, B. A., Navarro, S. L., Hannah, R. R., and Wood, K. V. (1996). Dualluciferase reporter assay: an advanced co-reporter technology integrating firefly and Renilla luciferase assays. Promega Notes 57, 2-8.

Shimodaira, Y., Takahashi, S., Kinouchi, Y., Endo, K., Shiga, H., Kakuta, Y., et al. (2014). Modulation of endoplasmic reticulum (ER) stress-induced autophagy by $\mathrm{C} / \mathrm{EBP}$ homologous protein (CHOP) and inositol-requiring enzyme $1 \alpha$ $(\mathrm{IRE} 1 \alpha)$ in human colon cancer cells. Biochem. Biophys. Res. Commun. 445, 524-533. doi: 10.1016/j.bbrc.2014.02.054

Soto-Avellaneda, A., and Morrison, B. E. (2020). Signaling and other functions of lipids in autophagy: a review. Lipids Health Dis. 19:214. doi: 10.1186/s12944020-01389-2

Swierczynski, J., Hebanowska, A., and Sledzinski, T. (2014). Role of abnormal lipid metabolism in development, progression, diagnosis and therapy of pancreatic cancer. World J. Gastroenterol. 20, 2279-2303. doi: 10.3748/wjg.v20.i9.2279

Swinnen, J. V., Heemers, H., Deboel, L., Foufelle, F., Heyns, W., and Verhoeven, G. (2000). Stimulation of tumor-associated fatty acid synthase expression by growth factor activation of the sterol regulatory element-binding protein pathway. Oncogene 19, 5173-5181. doi: 10.1038/sj.onc.1203889

Tanida, I., Ueno, T., and Kominami, E. (2004). Human light chain 3/MAP1LC3B is cleaved at its carboxyl-terminal Met121 to expose Gly120 for lipidation and targeting to autophagosomal membranes. J. Biol. Chem. 279, 47704-47710. doi: 10.1074/jbc.M407016200

Tempka, D., Tokarz, P., Chmielewska, K., Kluska, M., Pietrzak, J., Rygielska, Ż, et al. (2018). Downregulation of PARP1 transcription by CDK4/6 inhibitors sensitizes human lung cancer cells to anticancer drug-induced death by impairing OGG1-dependent base excision repair. Redox Biol. 15, 316-326. doi: 10.1016/j.redox.2017.12.017

Teres, S., Lladó, V., Higuera, M., Barceló-Coblijn, G., Martin, M. L., Noguera-Salvà, M. A., et al. (2012). 2-Hydroxyoleate, a nontoxic membrane binding anticancer drug, induces glioma cell differentiation and autophagy. Proc. Natl. Acad. Sci. U. S. A. 109, 8489-8494. doi: 10.1073/pnas.1118349109

Thompson, B. R., Hu, Y., and Smith, D. E. (2019). Mechanisms of gemcitabine oral absorption as determined by in situ intestinal perfusions in mice. Biochem. Pharmacol. 168, 57-64. doi: 10.1016/j.bcp.2019.06.013

Towbin, H., Staehelin, T., and Gordon, J. (1979). Electrophoretic transfer of proteins from polyacrylamide gels to nitrocellulose sheets: procedure and some applications. Proc. Natl. Acad. Sci. U. S. A. 76, 4350-4354. doi: 10.1073/pnas.76. 9.4350

Waddell, N., Pajic, M., Patch, A. M., Chang, D. K., Kassahn, K. S., Bailey, P., et al. (2015). Whole genomes redefine the mutational landscape of pancreatic cancer. Nature 518, 495-501. doi: 10.1038/nature14169

Walter, K., Hong, S. M., Nyhan, S., Canto, M., Fedarko, N., Klein, A., et al. (2009). Serum fatty acid synthase as a marker of pancreatic neoplasia. Cancer Epidemiol. Biomarkers Prev. 18, 2380-2385. doi: 10.1158/1055-9965.EPI-09-0144

Wang, J., and Nie, D. (2015). "Modulation of Autophagy by Free Fatty Acids," in Cell Death - Autophagy, Apoptosis and Necrosis, T. M. Ntuli (London: Intech Open). doi: 10.5772/61484

Wang, R. C., Wei, Y., An, Z., Zou, Z., Xiao, G., Bhagat, G., et al. (2012). Akt-Mediated Regulation of Autophagy and Tumorigenesis Through Beclin 1 Phosphorylation. Science 338, 956-959. doi: 10.1126/science.122 5967

Witkiewicz, A. K., Nguyen, K. H., Dasgupta, A., Kennedy, E. P., Yeo, C. J., Lisanti, M. P., et al. (2008). Co-expression of fatty acid synthase and caveolin-1 in pancreatic ductal adenocarcinoma: implications for tumor progression and clinical outcome. Cell Cycle 7, 3021-3025. doi: 10.4161/cc.7.19.6719

Wu, J., Dang, Y., Su, W., Liu, C., Ma, H., Shan, Y., et al. (2006). Molecular cloning and characterization of rat LC3A and LC3B-two novel markers of autophagosome. Biochem. Biophys. Res. Commun. 339, 437-442. doi: 10.1016/j. bbrc.2005.10.211

Yang, Y., Liu, H., Li, Z., Zhao, Z., Yip-Schneider, M., Fan, Q., et al. (2011). Role of fatty acid synthase in gemcitabine and radiation resistance of pancreatic cancers. Int. J. Biochem. Mol. Biol. 2, 89-98.

Yonekawa, T., and Thorburn, A. (2013). Autophagy and Cell Death. Essays Biochem. 55, 105-117. doi: 10.1042/bse0550105

Zhu, X., Zhou, M., Liu, G., Huang, X., He, W., Gou, X., et al. (2017). Autophagy activated by the c-Jun N-terminal kinase-mediated pathway protects human prostate cancer PC3 cells from celecoxib-induced apoptosis. Exp. Ther. Med. 13, 2348-2354. doi: 10.3892/etm.2017.4287

Conflict of Interest: PF-G and VL were employed by company Laminar Pharmaceuticals.

The remaining authors declare that the research was conducted in the absence of any commercial or financial relationships that could be construed as a potential conflict of interest.

Publisher's Note: All claims expressed in this article are solely those of the authors and do not necessarily represent those of their affiliated organizations, or those of the publisher, the editors and the reviewers. Any product that may be evaluated in this article, or claim that may be made by its manufacturer, is not guaranteed or endorsed by the publisher.

Copyright (c) 2022 Fernández-Díaz, Beteta-Göbel, Torres, Cabot, Fernández-García, Lladó, Escribá and Busquets. This is an open-access article distributed under the terms of the Creative Commons Attribution License (CC BY). The use, distribution or reproduction in other forums is permitted, provided the original author(s) and the copyright owner(s) are credited and that the original publication in this journal is cited, in accordance with accepted academic practice. No use, distribution or reproduction is permitted which does not comply with these terms. 